\title{
On the Association of Jelly-fish and other Organisms with Catches of Herring.
}

\author{
By
}

C. E. Lucas, B.Sc., and G. T. D. Henderson, Ph.D., B.Sc.

Department of Oceanography, University College, Hull.

\section{INTRODUCTION.}

Investigations into the relations between plankton and herring, using the Hardy Plankton Indicator, were carried out by this department during the years 1930 to 1933 (Hardy, Henderson, Lucas and Fraser, 1936). In planning this work Professor Hardy made provision for obtaining information, when possible, on weather conditions and on the occurrence of organisms which would not be caught in the plankton samples. Information on the presence of jelly-fish was specifically requested. Skippers of drifters using the Indicator were asked to fill in a printed label for each disc giving details of ship, date, time, position and catch, and the following sentence was printed at the foot of the label :"Any further notes regarding state of weather, sea, presence of jellyfish, or any unusual conditions may be written on the back."* Since the details of date, position, catch, etc., were essential for the success of the Indicator experiments, only these were definitely asked for, and skippers were left to supply further information if they had time to do so. Much more exact and extensive information regarding the presence of jellyfish and other organisms could have been obtained if the enquiry had been confined to these points, and it is hoped that this may be done in the future, either from this department or by other workers. Russell (1935, b), in stressing the importance of plankton organisms as indicators of different hydrological conditions, says "it is especially valuable to watch for any correlations between the presence or absence of certain plankton animals with that of fish and larger swimming animals." Our records, although not very extensive, are put forward as a contribution to this subject.

Russell $(1935$, a) has noted the close association between Cosmetira pilosella and Sagitta elegans in the waters off Plymouth. He concludes that both (together with other forms) are brought into this area by "western " water at times when a decreased flow of Atlantic water into

* These notes refer to conditions at the time of taking the sample and during the time that the gear was shot: 
the northern North Sea permits an increased flow of Channel water through the Straits of Dover. These forms (with others) are taken to be "indicators" of "western" or warm Atlantic water. The disturbing effects of Atlantic water on herring fisheries have previously been commented upon (Bowman, 1922, and Hardy, 1922). Savage (1926) suggests that small medusæ (as Obelia, Bougainvillea britannica, Phialidium hamispharicum and Lizzia blondina) "may react in a similar manner to Phoocystis when very abundant, but this is only a tentative suggestion." Again, it is not uncommon to hear drift fishermen associate poor catches with abundance of jelly-fish on the fishing grounds. In particular we may quote from The Fish Trades Gazette (22nd June, 1935) at. the time of the collapse of the spring herring fishery at Shields in 1935. "The fishermen say there are swarms of small jelly-fish in the sea on the usual fishing grounds." The Report of the Scottish Fishery Board for 1931 (1932, p. 65) mentions large numbers of medusæ (Laodicea, Tiaropsis, Cosmetira, Mitrocoma, Thaumantias and Obelia) as occurring in association with the squid Ommatostrephes, which was particularly abundant at the time of the breakdown of the Shetland herring fishery in 1931. Hjort (1912) refers to Ommatostrephes todarus pursuing the herring on the Norwegian coast. "They generally appear in enormous shoals, coming from the open ocean in pursuit of the herring shoals on which they gorge themselves greedily." The squid can be caught with herring as bait and they are in turn stored as bait for the cod fisheries. Dog-fish are often mentioned by fishermen as the causes of low catches even when herring are fairly abundant in the area, and whales and sharks possibly have a similar effect.

\section{JELLY-FISH.}

Of the 132 references to jelly-fish, 18 have the remark "No jelly-fish," and these have been omitted from consideration here, as there must have been many occasions when this statement could have been made, but was not. Of the remaining 114, some are indefinite as to type or quantity, but usually some expression is given of quantity, such as "few," " many " or "very many" and often brief notes of colour, size or type are added.

We may conveniently divide the records into a number of categories and will begin with those labelled "small." In each category we will give the catch associated with each particular label and with it also the average landing at the port, when that is available, for the weekly period in which the sample was taken. It will be realised that this is only of limited value since " jelly-fish" may have also been associated with many of the catches that go to make up this average but of which we have no record. The figure is given as a guide to whether the catch concerned is a high or a low one compared with the average of the fishery at the time.

Small jelly-fish are noted on twenty-two occasions. Eight of these may 
be classified as "few small," but one of these requires separation and special comment. The records of the seven remaining "few small " are tabulated in Table I, where we see that these figures in themselves are

\section{TABLE I.}

\section{Records Relating to "Few Small Jelly-Fish."}

\begin{tabular}{|c|c|c|c|c|c|c|}
\hline Date. & Area. & Remarks on labe & & & Catch. & $\begin{array}{l}\text { Av. catch } \\
\text { at port } \\
\text { for week. }\end{array}$ \\
\hline 5.6 .33 & Shields & Few small white* jelly-fish. & . & . & $0 \cdot 5$ & $4 \cdot 3$ \\
\hline 11.6 .33 & & white jelly-fish. & $\cdot$ & • & $1 \cdot 0$ & $2 \cdot 8$ \\
\hline 17.9 .31 & E. Anglia & Several small blue jellies. & . & . & $5 \cdot 0$ & $20 \cdot 9 \dagger$ \\
\hline 24.7 .31 & E. Scottish & A few squid and small jellies & . & . & $5 \cdot 5$ & $2 \cdot 8$ \\
\hline 0.7 .32 & & ,, small jellies . . & . & . & $9 \cdot 75$ & $17 \cdot 4$ \\
\hline 7.8 .31 & Shields & Few small jellies & . & . & . 14.0 & $6 \cdot 5$ \\
\hline 2.6 .32 & E. Scottish & A few small blue jelly-fish & . & - & . 18.0 & $7 \cdot 9$ \\
\hline
\end{tabular}

* The word white is italicised throughout for ready reference.

$\dagger$ Average of catches associated with Indicator discs.

insufficient to provide any reliable results. The one example separated from the rest is of interest in relation to the records which follow: it is from the Shields area (20.6.33) and gave a catch of 20 crans (port average of $6 \cdot 2$ crans). The label reads "Few small white jelly-fish in the first five nets and no herring in them." This record is separated from the other seven because the 20 -cran catch was taken outside the zone of small white jelly-fish. The possible significance of colour will be discussed when we have compared the data for the " many small " with the "few small" just recorded.

There are eleven records of "many small," two of which may be separated for special consideration. The remaining nine records are tabulated in Table II.

\section{TABLE II.}

\section{Records Relating to "Many Small" Jelly-fish.}

\begin{tabular}{|c|c|c|c|c|}
\hline Date. & Area. & Remarks on label. & Catch. & $\begin{array}{l}\text { Av, catch } \\
\text { at port }\end{array}$ \\
\hline 5.6 .33 & Shields & Large quantities of small white jellies . & $0 \cdot 0$ & $4 \cdot 3$ \\
\hline 10.6.33 &, & $\begin{array}{l}\text { Water in this area was full of small white } \\
\text { jellies. }\end{array}$ & $0 \cdot 0$ & $2 \cdot 8$ \\
\hline 28.9 .33 & E. Anglia & Many small white jellies when hauling . & $0 \cdot 0$ & $24 \cdot 4^{*}$ \\
\hline $\begin{array}{l}23.6 .32 \\
28.6 .32\end{array}$ & $\begin{array}{c}\text { W. Scottish } \\
,,\end{array}$ & $\begin{array}{l}\text { Large quantities of small white jelly-fish } \\
\text { Still getting large quantities of small white }\end{array}$ & $0 \cdot 0$ & $2 \cdot 5$ \\
\hline 10.7 .31 & Shields & $\begin{array}{l}\text { Large numbers of small white jelly-fish. All } \\
\text { drifters in 5-mile radius in all directions } \\
\text { practically blank. All report small white }\end{array}$ & $0 \cdot 5$ & $3 \cdot 0$ \\
\hline & & jelly-fish . . . & $1 \cdot 0$ & $16 \cdot 4$ \\
\hline 20.8 .31 & & Large numbers of small jellies & $2 \cdot 0$ & $7 \cdot 1$ \\
\hline $\begin{array}{r}9.7 .33 \\
7.6 .31\end{array}$ & E. Scottish & Many small blue jellies in water here. & $2 \cdot 0$ & $4 \cdot 2$ \\
\hline 7.6 .31 & , & Large number of small brown jellies. & $5 \cdot 0$ & $9 \cdot 1$ \\
\hline
\end{tabular}

* Having no port averages for this area, the average for the month of the remaining disc catches has been used. 
We see that in each instance the catch associated with " many small" jelly-fish is low and also considerably smaller than the port average. The catches are particularly small in relation to the "many small white" jelly-fish. This was also the case in the examples of even a "few small white" (see Table I and the special example in text), but as noted later there is one record labelled "small white jellies" with no indication of quantity, which has an associated catch of 35 crans. The two examples separated from Table II, together with that for July 10th, 1931, given in the Table, are of particular interest. From the Shields area (22.6.33) came the following note with an associated catch of 2 crans (average at the port $6 \cdot 2$ crans).

"Hauled 70 nets and got no herring at all, as they were full of small white jelly-fish, but the last 27 nets were clear of them and that was where we got the two crans of herring."

The second separated example is from the Eastern Scottish fishery (18.7.33) associated with a catch of 6 crans (port average $4 \cdot 2$ crans).

"Many small white jellies in the water and nets at hauling time. These jellies went down (?) towards daylight and we found the six crans in those nets hauled after this time."

In each case, as in the one previously cited, the herring were taken outside the zone where the small white jelly-fish were visible. In the last example the skipper queries his remark "down." As a drifter hauls her nets, she moves slowly through the water and it is possible that she passed out of the zone of jelly-fish into a region clear of them where the six crans were taken.

The evidence suggests that "many small" jelly-fish, particularly " many small white" jelly-fish, are indications of poor catches. This receives further support from a comparison of the average of the catches associated with "few small" jelly-fish, "many small" jelly-fish and " many small white" jelly-fish respectively.

$$
\begin{aligned}
& \text { Average catch with " few small " jelly-fish } \quad=9 \cdot 3 \text { crans ( } 8 \text { samples) } \\
& \text {, , , ", "many small " jelly-fish }=1 \cdot 7, \text { (11 samples) } \\
& \text {, , , , " "many small white" jelly-fish }=1 \cdot 2, \text {, (8 samples) }
\end{aligned}
$$

There are three records of small jelly-fish with no indication of quantity ; they are as follows :-

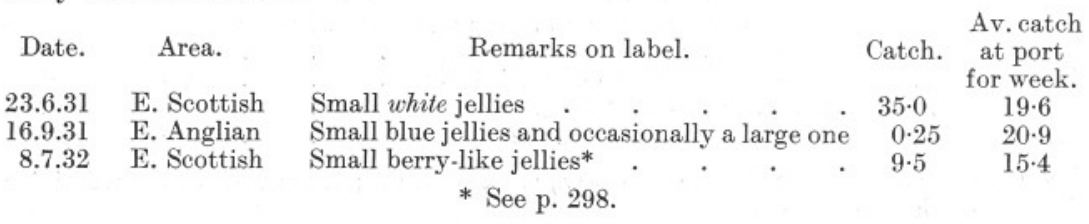


There are seven records in which the notes refer to "many large" jelly-fish being present, all of which were recorded off Shields in July, 1931. These are given in Table III. In two instances the catch is approximately equal to that of the port, in two it is lower than the port average, and in three it is higher than the average. There is one other record of "large " jelly-fish included in the category of "stinging" jellyfish.

\section{TABLE III.}

\section{Records Relating to "Large" Jelly-fish in the Shields} Fishery, July, 1931.

Date.

July 6

July 27

July 11

July 24

July 16

July 20

July 18

$$
\text { Remarks on label. }
$$

$\begin{array}{cc}\text { Catch. } & \begin{array}{c}\text { Av. catch } \\ \text { at port } \\ \text { for week. }\end{array} \\ 7 \cdot 0 & 16 \cdot 4 \\ 11 \cdot 0 & 17 \cdot 1 \\ 17 \cdot 0 & 16 \cdot 4 \\ 20 \cdot 0 & 20 \cdot 4 \\ 35 \cdot 0 & 15 \cdot 2 \\ 41 \cdot 0 & 20 \cdot 4 \\ 48.0 & 15 \cdot 2\end{array}$

We may next take those labelled in regard to colour but not size ; these are given in Table IV. Here we see that in ten samples out of twelve the average at the port was higher than the catches associated with the jelly-fish.

\section{TABLE IV.}

\section{Records giving Colour Notes Relating to Jelly-fish

\begin{tabular}{|c|c|c|c|c|c|c|c|c|c|}
\hline \multirow{2}{*}{$\begin{array}{l}\text { Date. } \\
6.7 .32\end{array}$} & \multirow{2}{*}{$\begin{array}{c}\text { Area. } \\
\text { Shields }\end{array}$} & \multicolumn{5}{|c|}{ Remarks on label. } & & Catch. & $\begin{array}{l}\text { Av. catch } \\
\text { at port } \\
\text { for week. }\end{array}$ \\
\hline & & Large quantities & of whit & jellies & & . & ${ }^{\circ}$ & $3 \cdot 0$ & \\
\hline 12.5 .32 & & Few white jellies & . & . & . & . & . & $0 \cdot 0$ & $4 \cdot 3$ \\
\hline 11.7 .32 & E. Scottish & 1 or 2 blue jellies & . & . & . & . & . & $10 \cdot 0$ & $11 \cdot 9$ \\
\hline 15.7 .32 & , , & Blue jellies & . & . & . & . & . & $9 \cdot 0$ & 11.9 \\
\hline 18.7 .32 & , , &,,$\quad$, & . & . & . & . & . & $7 \cdot 0$ & 11.9 \\
\hline 19.7.32 &, &,,$\quad$, & . & . & & . & . & $1 \cdot 0$ & $11 \cdot 9$ \\
\hline 20.7 .32 &, & Several blue and & brown & jellies & 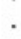 & . & & $5 \cdot 5$ & $11 \cdot 9$ \\
\hline 2.7 .31 & & Brown and blue j & jellies & . & & & & 0.5 & $16 \cdot 0$ \\
\hline 21.7 .31 & , , & Blue and brown j & jellies & . & . & & & $0 \cdot 25$ & $1 \cdot 4$ \\
\hline 19.6 .31 & , & $, \quad, \quad$, & , & . & . & . & & $8 \cdot 0$ & $9 \cdot 1$ \\
\hline 18.6.31 &, , & ,, & ,, & . & ${ }^{\circ}$ & . & & $20 \cdot 0$ & $9 \cdot 1$ \\
\hline 20.6 .31 & , & , , &, & . & . & . & & $32 \cdot 0$ & $9 \cdot 1$ \\
\hline
\end{tabular} But no Indication of Size.}

In Table $\mathrm{V}$ there are ten records of "stinging" jelly-fish, the whole averaging 9.4 crans, and the catches ranging from $0 \cdot 0$ to $32 \cdot 0$ crans. There are one or two points in connection with these which are of interest.

The five records between June 30th and July 31st are from Scottish waters (area $58^{\circ}-59^{\circ} \mathrm{N}$.) and the catches averaged $3 \cdot 7$ crans (all being less 
than the corresponding port averages); of these, three low catches were associated with dense patches of diatoms (marked $\dagger$ ) or Phæocystis $($ marked $*$ ) which may account to some extent for the low average compared with the remainder of these records. In 1932 there was only one record, on July 14th, with a catch of 9 crans. The remaining four records are in the Shields area during the first half of August, 1933, and they have an average catch of 16.8 crans : these and the 1932 Scottish catch were all higher than the port averages. The Scottish records in 1931 are

\section{TABLE V.}

Records Relating to "Stinging" or "Burning" Jelly-fish.

\begin{tabular}{|c|c|c|c|c|}
\hline ate. & Area. & Remarks on label. & Catch. & $\begin{array}{l}\text { Av. catch } \\
\text { at port } \\
\text { for week. }\end{array}$ \\
\hline 3.7 .31 & E. Scottish & $\begin{array}{l}\text { Stinging jellies. Alongside of ship are count- } \\
\text { less numbers of minute fish. Caught some } \\
\text { in basket. They were adhering to jelly- } \\
\text { fish. Gear full of evil-smelling, greenish- } \\
\text { coloured slime.*t. }\end{array}$ & $0 \cdot 0$ & $15 \cdot 2$ \\
\hline 30.7 .31 & , & $\begin{array}{l}\text { A few stinging jellies. . Water very clean. } \\
\text { There were catches here to-night up to } 90\end{array}$ & & \\
\hline & & crans. Herring very spotty . & $0 \cdot 125$ & $2 \cdot 9$ \\
\hline 2.7 .31 & ,, & $\begin{array}{l}\text { Stinging jelly-fish. Also nasty dirty yellow- } \\
\text { ish substance. }{ }^{+}+\end{array}$ & $1 \cdot 5$ & $15 \cdot 2$ \\
\hline 30.6 .3 & ,, & $\begin{array}{l}\text { Jelly-fish of the stinging and burning } \\
\text { variety. } \dagger\end{array}$ & $3 \cdot 25$ & $15 \cdot 2$ \\
\hline 1.7 .31 & , & $\begin{array}{l}\text { Stinging jelly-fish in abundance. Several } \\
\text { catches up to } 50 \text { crans caught in near } \\
\text { vicinity }\end{array}$ & 13 & $15 \cdot 2$ \\
\hline .7 . & & llies, burning and others & & \\
\hline 38 & Shields & & $8 \cdot 0$ & $4 \cdot 7$ \\
\hline & ," & $y$-fish & $12 \cdot 0$ & $4 \cdot 7$ \\
\hline 6.8. & ,", & 10 & $15 \cdot 0$ & $4 \cdot 7$ \\
\hline 8.8.33 &, & A few big stinging jelly-fish & $32 \cdot 0$ & $4 \cdot 7$ \\
\hline
\end{tabular}

all from the same observer, and it may be reasonable to deduce that they refer only to one type of jelly-fish. A note attached to one runs as follows: "Stinging jellies. Alongside of ship are countless numbers of minute fish. Caught some in basket. They were adhering to jelly-fish. Gear full of evil-smelling, greenish-coloured slime." These fish were sent to the laboratory together with the disc, and were found to be young Gadus merlangus: it seems possible that the medusæ were Cyanea, commonly found in association with young whiting (Russell, 1931). The disc was covered with Phæocystis, and some diatoms were also recorded.

A "cut crystal" variety of jelly-fish is mentioned twice, with associated catches of 1 and $11 \frac{1}{2}$ crans : on the second of these a note is added, "Herring never are plentiful amongst these." "Small berrylike jellies" (possibly Pleurobrachia) are recorded once, with a catch of 
$9 \frac{1}{2}$ crans. (The catches associated with these three discs are all less than the corresponding port averages.)

In addition to the records already dealt with, there are fifty* in which quantity only is recorded: these are shown in Table VI, together with their corresponding port averages. Although described under various headings, broadly they can be grouped under the heads of "many" or "few" jelly-fish. The figures are as follows :-

$$
\begin{array}{ccccc} 
& & \text { Scotland. } & \text { England. } & \text { Total. } \\
\text { Average catch with " many " jelly-fish } & 9 \cdot 6(10) & 12 \cdot 3(29) & 11 \cdot 6(39) \\
\text { ", ", ", "few " jelly-fish } & 15 \cdot 3(5) & 18 \cdot 1(6) & 16 \cdot 8(11)
\end{array}
$$

(The figures in brackets denote the number of catches averaged.) Thus, as far as we can place reliance on this type of comparison, we see that there is a consistency in the relations of the catches associated with " many" and "few" jelly-fish. Their relation with the corresponding catches at the port is shown below.

$\begin{array}{clccc}\text { Area. } & \text { Category. } & \begin{array}{c}\text { Number } \\ \text { of } \\ \text { samples. }\end{array} & \begin{array}{c}\text { No. in which } \\ \text { port a verage } \\ \text { is higher. }\end{array} & \begin{array}{c}\text { No. in which } \\ \text { port average } \\ \text { is lower. }\end{array} \\ \text { Scotland } & \text { Many } & 10 & 6 & 4 \\ \text {," } & \text { Few } & 5 & 3 & 2 \\ \text { England } & \text { Many } & 29 & 19 & 10 \\ \text {," } & \text { Few } & 6 & 5 & 1 \\ \text { Total S. and E. } & \text { Many } & 39 & 25 & 14 \\ \text { ", ", } & \text { Few } & 11 & 8 & 3 \\ \text { Grand total } & & 50 & 33 & 17\end{array}$

In each category we see that the port average is more often higher than that of the catches associated with jelly-fish than lower.

The information regarding jelly-fish put forward here can only be considered as a tentative beginning to a more extensive accumulation of data which it is hoped may be built up in the future by different workers. It does suggest that a definite negative relation exists between the herring and an abundance of "small jelly-fish" and particularly the " small white jelly-fish." This relationship may extend beyond these categories, but we must bear in mind the possibility of different types of jelly-fish bearing different relationships to the herring. The term jelly-fish may, in any of the waters investigated, refer to medusæ or ctenophores, and in the Scottish waters it is not impossible that salps or doliolids may be referred to (Bowman, in 1922, associated an influx of salps with the poor herring fishing of 1921). The indications revealed here would appear to warrant

\footnotetext{
* Eleven other records mention jelly-fish but give no further details, the catches ranging from $0 \cdot 0$ to $28 \cdot 0$ crans, and averaging $7 \cdot 3$ crans.
} 
further researches and it is in the hope that further interest may be aroused in this problem (see also Russell, 1935, b) that we publish these scanty data.

The bulk of the data refers to 1931, and it seems possible that this year was characterised by a greater abundance of "jelly-fish," visible on the fishing grounds generally, than the years 1932 and 1933.

\section{Squid.}

The Report of the Scottish Fishery Board for 1931 (1932) refers to the occurrence in $1930^{*}$ of the squid Ommatostrephes sagittatus whose " appearance in large numbers on the drift-net grounds was almost synchronous with the sudden and complete break in the drift-net fishery." $\uparrow$ They were again abundant on the grounds in 1931, but further south. In $1932 \ddagger$ they were reported as being neither troublesome nor numerous.

With the exception of two between Lats. $59^{\circ}-60^{\circ} \mathrm{N}$. our records associated with squid were obtained in the area between Lats. $58^{\circ}$ and $59^{\circ} \mathrm{N}$. and between June 30th and July 30th, 1931 ; the average catch was $1 \cdot 5^{14}$ crans. The average for all our samples in that area in July was $4 \cdot 0^{26}$ crans. Of the sixteen samples, thirteen are fairly definite as to quantity and three are vague : they are listed in Table VII. Five catches noting "few squid" averaged $10 \cdot 6^{5}$ crans : four noting "some squid" averaged $1 \cdot 0^{4}$ crans, and four noting " many squid " averaged $0 \cdot 5^{4}$ crans. Of the 16 catches, 13 were lower than the corresponding weekly port averages. This scanty material suggests a negative correlation between squid and herring catches.

\section{Dogfish, Whales and Sharks.}

The Report of the Scottish Fishery Board for 1930 (1931, p. 21) refers to fishermen on the West Coast being troubled with basking sharks, dogfish and other pests. In 1931 we received a brief report from a skipper who had taken samples for us in late June and July off the Scottish coast. Part of this runs, "Squids, dogs and foul marine growth all were too numerous in the northern waters this season. Especially the east sides of Orkneys and Shetlands. On the west side of Orkneys and the northwest side of Scotland there were no squids. Dogs there always are and only a few jellies."

There seems to be a general consensus of opinion among fishermen that whales, sharks and particularly dog-fish, cause considerable harm by driving the herring away from their feeding and spawning grounds. As

\footnotetext{
* See also Ann. Rep. Fish. Bd. Scot. for 1930 (1931), pp. 20-21, where squid and cuttlefish are reported as infesting the usual grounds.

$\dagger$ See Introduction for reference to Hjort.

‡ Ann. Rep. Fish. Bd. Scot. for 1932 (1933), p. 18.
} 
far as our records go, the last seem to have been relatively very abundant in 1931, compared with 1932 and 1933 . We have 29 references to their presence during fishing operations and they can be classified as follows :-

General Remarks.

Associated catches. Av. catch.

"Few" or " several" dog-fish $0, \frac{1}{8}, 1,1 \frac{1}{4}, 2 \frac{3}{4}, 15,16,17$ and $30 \quad 9 \cdot 2^{9}$

"Many" dog-fish $\quad 0,0,0,0, \frac{1}{8}, 1,1,3,12_{4}^{3}$ and $51 \quad 6.910$

Dog-fish (no indication of quantity) $\quad 0,0,0, \frac{1}{2}, \frac{1}{2}, 1,1,2,20$ and $40 \quad 6 \cdot 5^{10}$

Indices denote number of catches averaged.

Ten references to whales suggest that catches may be small when they are present. The average catch is $4 \cdot 0^{10} \mathrm{crans}$, and the catches range from $0 \cdot 0$ to 13.5 crans. There were four references in 1931 and six in 1932 . Seals and porpoises are mentioned in conjunction with two of these catches.

There are two references to sharks, with catches of 8 crans and $\frac{1}{2}$ box.

\section{SUMMARY.}

1. An attempt is made to relate catches of herring to the local abundance of associated jelly-fish, squid, dog-fish, etc. The data are derived from fishermen's descriptions of conditions at the time of fishing.

2. The observations as a whole suggest an avoidance by the herring of large numbers of jelly-fish.

3. Detailed results suggest that the herring tend most to avoid large numbers of " small" jelly-fish and particularly " small white" jelly-fish. This relationship also seems to extend to a group of observations in which colour is given with no indication of size. In two categories, particularly noted as "large " and "stinging" jelly-fish, this negative association is absent.

4. There is some evidence of a negative association between herring and the presence of large numbers of squid, dog-fish and whales. 


\section{REFERENCES.}

Bowman, A. 1922. The Biological Interchange between the Atlantic and the North Sea. Rep. Brit. Assoc. Adv. Sci., p. 367. London.

Hardy, A. C. 1922. Notes on the Atlantic Plankton taken off the East Coast of England in 1921 and 1922. Cons. Perm. Int. pour l'explor. de la mer. Pub. de Circ. No. 78. Copenhagen.

Hardy, A. C., Henderson, G. T. D., Lucas, C. E., and Fraser, J. H. 1936. The Ecological Relations between the Herring and the Plankton investigated by the Plankton Indicator. Parts I-IV. Journ. Mar. Biol. Assoc., N.S., Vol XXI, No. 1, p. 147.

HJorт, J. 1912. (In Murray and Hjort) The Depths of the Ocean, p. 648. London.

Russell, F. S. 1931. Notes on Cyanea caught in the Ring-trawl in the Plymouth Area during the years 1925 to 1930. Journ. Mar. Biol. Assoc., N.S., Vol. XVII, No. 2, p. 573. Plymouth.

1935, a. On the Value of certain Plankton Animals as Indicators of Water Movements in the English Channel and North Sea. Journ. Mar. Biol. Assoc., N.S., Vol. XX, No. 2, p. 309. Plymouth.

1935, b. A review of some aspects of Zooplankton Research. Cons. Perm. Int. pour l'explor. de la mer. Rapp. Proc. Verb. XCV, p. 5. Copenhagen.

Savage, R. E. 1926. The Plankton of a Herring Ground. Min. of Agric. and Fish., Fish Invest., Ser. II, Vol. IX, No. 1. London.

1935. The Fish Trades Gazette, Vol. LIII, No. 2717. Aberdeen.

1931-33. The 49th, 50th and 5lst Annual Reports of the Fishery Board for Scotland, for the years 1930-32. Edinburgh. 


\section{TABLE VI.}

Records Relating to Quantities of Jelly-fish, But with no Indication of Size, Type or Colour.

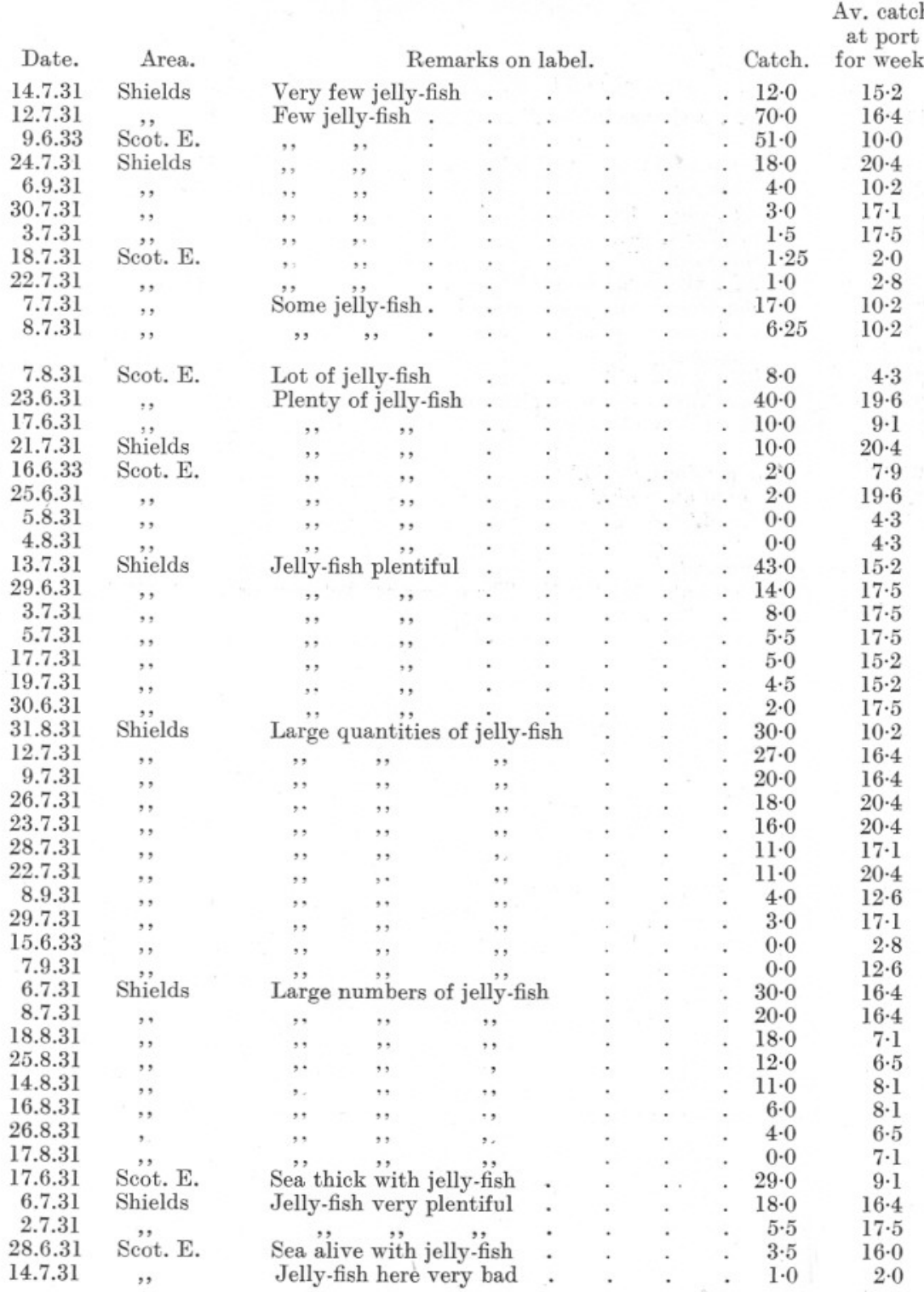

Note.-Scot. E. denotes the Scottish Eastern Fishery. 


\section{TABLE VII.}

\section{Notes on the Occurrence of Squid with Herring catches} in Scottish Waters, 1931.

Catch.

Av. catch at port

Date.

Remarks on label.

$29 \cdot 0$

for week,

17.6.31† " . . . a chance inkfish." $9 \cdot 1$

17.7.31†

"A few squid and dogfish."

$15 \cdot 0$

$6 \cdot 7$

30.6 .31

27.7.31

2.7.31

14.7.31

22.7 .31

9.7.31

15.7.31

30.7 .31

29.7.31

28.7.31

"A few squid and small jellies."

" . . . also a few squid." .

" Squids, a few."

"Some squid."*

" ". . . also some squid and a few jellid

"Some squid and a few jellies.'

" . . . some squid."

" . . . many squid."

" Plenty squid.

$5 \cdot 5$

$3 \cdot 25$

$0 \cdot 25$

1.5

1.0

$1 \cdot 0$

0.5

1.25

0.5

"Squid and dogs were plentiful." . . . . . 0.125

$0 \cdot 0$

$2 \cdot 8$

$15 \cdot 2$

$2 \cdot 9$

$15 \cdot 2$

21.7.31

"'Some dogs, squid."

$2 \cdot 75$

"Squid and dogs." . . . . . . . . . . 2.0

23.7.31

17.7 .31

"Squid."

* Phæocystis present.

$\dagger$ Taken between Lats. $59^{\circ}-60^{\circ} \mathrm{N}$. The others are between Lats. $58^{\circ}-59^{\circ} \mathrm{N}$. 